\title{
Introduction to the Core Concepts of Christian Psychotherapy
}

\author{
Prof. Naum Ilievski \\ PhD, Faculty of Psychology, International Slavic University “Gavrilo R. Derzhavin”, \\ Sveti Nikole, R. North Macedonia \\ Angelina llievska \\ MD, Psychotherapist, Psychiatrist, Private Practice, Skopje, R. North Macedonia
}

\begin{abstract}
Christian psychotherapy comes out of the two-thousand year long spiritual practice in Christianity. Its core is based upon the foundations of Christian anthropology, which defines and focuses on the human soul. The purpose of this paper is to establish Christian psychotherapy as a contemporary theory of personality development, with its own method that enables personality development and growth to a complete spiritual selfactualization and self-realization. Christian psychotherapy opens a new perspective towards man's psychological and spiritual functioning; a new dynamic model is offered for his inner functioning - not only at a psychological, but also at a spiritual level - which is useful and practically applicable with the other trends in psychotherapy. Via a descriptive method, the basic concepts are defined: (1) Stages of spiritual development; (2) A comparative parallel between the stages of spiritual development and the stages of spiritual and mental disorders with clinical psychopathological entities; (3) Primary and secondary function of the mind; (4) The FCP method (systematized by the author), which has a central role, and the client-therapist relationship; The systematization of the spiritual development of personality is found only within the frames of Christian psychotherapy; this type of systematization of the spiritual development - including a parallel comparison with the three stages of spiritual and mental disorders - has been introduced for the first time.
\end{abstract}

Keywords: stages of spiritual development, primary and secondary function of the mind, pure mind, spiritual intellect, FCP method, healing

\section{Introduction}

Man is a dynamic being. He is created as a person with a soul and body, in the image and likeness of the Creator (cf. Gen. 1,26).

In accordance with the biblical anthropology and patristic interpretation, this spiritual pre-model is the complete and ultimate level that man should achieve. "In order to realize this aim, great powers and potentials, abilities and strivings are incorporated in human nature; man can set them in the right direction by using his free will, that is, by forming an eternal, loving and free union with God and his neighbors" (llievski and Jovkovska, 2018, pp. 189-190).

From the aspect of contemporary personality theories in the field of psychology, the ultimate reach in man's development is the result of the tendencies of his civilizational superstructure - the super-ego, achieving higher moral and ethical principles, and self-realization as a social and individual being. This is the ethical level of functioning.

This paper deals with a deeper and more essential existence of the individual, that is, with an overall and complete realization of his ontological predetermination. In that way, striking existential issues arise, which regard man as an aesthetic image, whose greatest potentials and strivings are in his spiritual self.

There are many authors that have made the concept of man's spiritual existence a central aspect in their theories of personality. In that respect, Viktor Frankl develops an entire division - logotherapy, where a central premise is man's search for meaning. Thus, in psychology and psychotherapy "The Third Viennese School of Psychotherapy" (Frankl, 1992, 
p. 10) is formed, beside the previous two - Freud's psychoanalysis and Adler's individual psychology. Frankl found that the role of the therapist, then, is to help the patient discover purposefulness in life (Frankl, 1988, p. x).

The founder of Transpersonal psychology, Abraham Maslow, writes about man's transpersonal dimension realized by the process of self-actualization of the "unique selfhood" (Grinstead, 1990, p. 4). "Self-actualization is ongoing - growth oriented, it is a pressings forward to fullness - good values, serenity, kindness, courage, honesty, love, unselfishness and goodness" (Maslow, 1968, p. 155).

Christian psychotherapy, like other trends in psychotherapy that focus on the spiritual development of personality, undoubtedly positions itself as "The Fourth Spiritual School of Psychotherapy," within the current theories and applied approaches.

\section{Stages of Spiritual Development}

Struggle, as an act of dynamic movement from an image to likeness of the Creator, is the foundation of spiritual development. It is a process of man's spiritual growth and perfection, as well as the basis and content of Christian psychotherapy.

In practical Christian spiritual life, there are stages of spiritual development systematized by the author (llievski, 2015, pp. 165-173).

\section{Fig. 1. - Table of the Harmony of the Ascetic-hesychastic Struggle}

(according to which everyone can find his place on the ladder of spiritual development, become aware and reconcile the mode of his personal struggle in accordance with his spiritual development and position in the Church)

\begin{tabular}{|c|c|c|c|c|c|c|c|c|}
\hline $\begin{array}{l}\text { Stages of } \\
\text { spiritual } \\
\text { development }\end{array}$ & $\begin{array}{l}\text { What is the } \\
\text { prayer like }\end{array}$ & $\begin{array}{l}\text { What is } \\
\text { purified }\end{array}$ & $\begin{array}{l}\text { What is } \\
\text { stressed in } \\
\text { the struggle }\end{array}$ & $\begin{array}{l}\text { The temptations } \\
\text { are mainly }\end{array}$ & $\begin{array}{l}\text { The mode of } \\
\text { organization of } \\
\text { monastic life }\end{array}$ & $\begin{array}{l}\text { Clerical } \\
\text { rank }\end{array}$ & Obedience & Love \\
\hline PURIFICATION & $\begin{array}{l}\text { oral or with } \\
\text { the mind }\end{array}$ & $\begin{array}{l}\text { the energy } \\
\text { of the mind }\end{array}$ & $\begin{array}{l}\text { placing of } \\
\text { the mind in a } \\
\text { process of } \\
\text { healing (ascetic } \\
\text { humility) }\end{array}$ & $\begin{array}{l}\text { from within } \\
\text { (due to the } \\
\text { captivity to } \\
\text { passions) }\end{array}$ & coenobium & deacon & $\begin{array}{l}\text { absolute or } \\
\text { blind } \\
\text { obedience }\end{array}$ & eros \\
\hline $\begin{array}{l}\text { II. } \\
\text { ILLUMINATION }\end{array}$ & \begin{tabular}{|l} 
ascetic \\
mind-and- \\
heart \\
prayer
\end{tabular} & $\begin{array}{l}\text { the essence } \\
\text { of the mind } \\
\text { (which is in } \\
\text { the heart) }\end{array}$ & $\begin{array}{l}\text { keeping of the } \\
\text { mind within the } \\
\text { heart and love } \\
\text { toward one's } \\
\text { enemies }\end{array}$ & $\begin{array}{l}\text { from outside } \\
\text { (through people) }\end{array}$ & skete & presbyter & $\begin{array}{l}\text { depends on } \\
\text { the level at } \\
\text { which one's } \\
\text { spiritual } \\
\text { father is }\end{array}$ & $\begin{array}{l}\text { friendship } \\
\text { (closeness) }\end{array}$ \\
\hline GODLIKENESS & $\begin{array}{l}\text { unceasing } \\
\text { or graceful } \\
\text { mind-and- } \\
\text { heart } \\
\text { prayer }\end{array}$ & $\begin{array}{l}\text { deification } \\
\text { of the whole } \\
\text { man - both } \\
\text { body } \\
\text { and soul }\end{array}$ & $\begin{array}{l}\text { prayer and } \\
\text { mourning for } \\
\text { the whole } \\
\text { world }\end{array}$ & $\begin{array}{l}\text { from outside } \\
\text { (through people } \\
\text { and from the } \\
\text { demon himself) }\end{array}$ & hermitage & bishop & not to a man & love \\
\hline
\end{tabular}

This kind of systematization is the basic matrix of Christian psychotherapy. It essentially represents the evolution of spiritual growth and personality development.

At the first stage of his spiritual development, man enters in obedience, that is, he places his mind in a process of healing by an act of his free will. Furthermore, he grows, perfects himself and - from an individual - becomes a person through personal ascesis (struggle of self-enforcing) and a process of metanoia ("a change of mind" through which one directs his entire life towards the Creator). Thus, he realizes his spiritual predetermination - godlikeness.

This is the upward vertical line of human existence; diametrically opposed is the downward vertical line of mental and spiritual disorders.

There is a scientific systematization of the stages of mental disorders and - although evident in the practical spiritual life a systematization of Christian psychotherapy and a description of how man is perfected have not been made yet. So far, 
there is only a systematization of the spiritual development; however, it has not been ultimately elaborated as a psychotherapeutic method.

There are two reasons. First, the three stages of spiritual development are often overlooked - purification of the heart from the passions, illumination of the mind with the gift of the mind-and-heart prayer (the highest form of prayer in which the mind is kept in the heart without distraction), and deification. Second, the functional difference between the pure mind and the intellect has not been taken into account.

The overlooking of the three stages of spiritual development leads to great ambiguity when classifying spiritual phenomena, while the overlooking of the functional difference between the mind and the intellect leaves the entire Christian psychotherapy process (that is, struggle) vague.

Therefore, the purpose of this paper is to describe the above-mentioned phenomena by presenting and defining the following core concepts of Christian psychotherapy:

1) Stages and dynamics of the spiritual level of existence.

2) Differences between a person and an individual.

3) Functions of the mind.

4) Differences between pure mind and intellect.

5) Precise explanation of human nature.

6) The five control point method (FCP).

7) Description of the stages of spiritual and mental disorders and healing.

\section{Spiritual Level of Existence}

In contemporary scientific psychology, the highest achievement in human psycho-social functioning is the morality level as a manifestation of ethics.

In Christian psychotherapy, man is determined to become a person out of an individual, through the three stages of spiritual development, that is, through the process of metanoia of his fallen mind and nature, and its transformation to perfection until the stage of deification is reached. At this level, one can speak of spiritual aesthetics.

The moral and ethical principle is realized at the level of super-ego. This paper describes how the spiritual level is realized by the spiritual self - "the inner core of the self" (James, 1981, pp. 54-65), as well as the transformation of the soul and its powers. At this point, the issue about the differentiation of the psyche arises - between soulfulness and spirituality - as an apparatus that exists and manifests itself in the psychological structures and functions, in contrast to the spiritual dimension of the soul, by which man realizes his natural predetermination - to become a person.

The spiritual dimension and spirituality are elaborated in contemporary literature by many authors, who make an attempt to define it. According to Rebecca L. Trautmann, in her article Psychotherapy and Spirituality (2003, pp. 32-36), spirituality is the process through which human beings transcend themselves. For those who believe in God, spirituality is their experience of this relationship with God. It takes us beyond ourselves into a realm wherein "we can experience a union with something larger than ourselves, and in that union find our greatest peace" (James, 1917, p. 515).

\section{Person vs. Individual}

What is the difference between an individual and a person, from a Christian viewpoint? One can speak about a person only when referring to those who - being obedient towards a spiritual father in the Church - have made a step on the way to the first stage of their spiritual development, along the path of purification of the heart from the passions. An individual is at some of the stages of mental disorders: neurosis, personality disorders and psychosis, outside the stages of spiritual development, living in sin (Gr. a a apría - literally, "missing the mark," i.e. missing the mark of godlikeness, resulting in alienation from the Divine), that is, according to the principles of his fallen nature, outside of his spiritual ontological predetermination.

Christian anthropology deals with the human soul (Gr. $\psi u x n$ - the spiritual or immaterial part of a human being, regarded as immortal) and its three powers: the rational, which is related to the mind, and the two irrational: the will and the desire (Hierotheos, 2008). Their center is the spiritual heart. These drives need to function in accordance, in order to produce psychological and spiritual harmony, which is a reflection of mental and spiritual health. 
In that respect, a parallel to the psychoanalytic tripartite structural model of the human psyche is made, where the psychological energy of the libido circulates through its powers (Freud, 1923).

Namely, using these terms, the rational part corresponds to the ego and the super-ego, while the irrational powers correspond to the unconscious part - the id, as a source of volitional and instinctive dynamisms. Hence, the passive principle of the natural will is born as opposed to the rational will, which comes out from the essential nature and is the basic drive in the ascetic-hesychastic struggle (Migne, PG 91, 280a).

\section{Primary and Secondary Function of the Mind}

Regarding the dynamic model of Christian psychotherapy, the significance of the above-mentioned division of the two functions of the mind should be outlined. Such differentiation depends on the basic directedness of the essential energy of the mind: intra-psychic - towards the spiritual self, or extra-psychic - by the ego functions towards the external world.

The energy of the mind has two functions - primary and secondary. Using the primary function, the mind communicates directly to the transcendental aspect - the Divine, while using the secondary function it communicates with the world.

This is the key point that determines human existence, whether it is only at a psychological or at a higher, spiritual level as well. Every man is given this potential, but its realization depends on his free will.

The primary function of the mind is set into motion by the rational will, and thus a personal and direct communication with the Divine is realized. This is a process of creating a personal relationship with the Creator, achieving complete spiritual development. In addition, the given potential of the spiritual self is activated and the individual becomes a person - the utmost development level of self-realization and self-actualization.

The secondary function of the mind is manifested by the intellect; using this function, man communicates with the external world through the ego apparatus.

\section{The Difference between Pure Mind and Intellect}

Man usually lives in his existential split, between what he is and what he is supposed to become. Few people are aware of what is the root cause of their dualism while choosing between the attraction of the worldly and the necessity of the Divine.

The basic aim, which is acquiring of spiritual intellect (Митрополит Струмички Наум, 2018, pp. 173-174), is achieved by overcoming the dualism between the pure mind and the intellect. The energy of the mind acts towards the world in a transformed manner, with a changed perspective of one's worldview and realization of the spiritual principles in his everyday life. This process can be achieved by integrated co-acting of the primary and secondary function of the mind.

According to the Christian psychotherapy, without the reconciled activity of the primary and secondary function of the mind, which comprises healing of the mind, the personality development and the realization of one's personal identity are not possible (llievski, 2015, p. 168).

In the process of transformation (metanoia), the energy of the mind is the first to be transformed, by its primary function a prayerful union with God, that is, by His uncreated energy; once its energy is transformed, it acts in accordance with its secondary function - communication with this world. In that way, the mind - qualitatively changed - acts towards the realization of spiritual principles (Митрополит Струмички Наум, 2016, pp. 181-182).

\section{Structure and Dynamics of the Human Nature}

During the usual psychological functioning, a part of the volitional dynamisms - by the natural will - is constantly directed towards nature, into the basis of which are primordial pulses. This is a centrifugal dissemination of the driving force, élan vital (Bergson, 1911, p. 88), towards the id, with a downward vertical movement.

In addition, the energy is directed horizontally towards the ego, its cognitive functions and its defense mechanisms, which enable reality testing, congruent behavior, social integration and an overall psychological equilibrium. 
As described above, the psychological and energetic dynamics is at the level of the secondary function of the mind. This function is called intellect.

The primary function is a centripetal force of contraction, which collects the mind in the heart and by ascesis in hesychia (stillness) heads for a vertical direction, theocentrically, towards the existence of the Divine. The primary function of the mind is called a state of pure mind.

With his individual free choice, man can be set in motion by the passive principle of the natural will and realize the impulses of his fallen nature (instinctive dynamisms and pulses), and activate the secondary function of the mind - the intellect, which is manifested by scattering of the energy of the mind through the senses towards the external world.

The action in the opposite perspective is an ascetic struggle of one's own free will, by directing the energy of his mind in its primary function - into the spiritual heart (llievski and llievska, 2017, pp. 96-97).

This means that the driving force will no more be used merely for satisfaction of the instinctive dynamisms and egofunctions, but for realization of a practical spiritual life with fulfilment of the divine commandments.

\section{The FCP Method}

The FCP method has a central role in the Christian psychotherapy (llievski and llievska, 2017, pp. 93-98). For the first time the author has systematized it and consists of the following five points: (1) acceptance; (2) thanksgiving; (3) selfdiscernment; (4) not showing one's inner state, and (5) prayer. This process is also known as transformation.

The essential reach of the FCP method are higher states of prayer and illumination of the mind, as a way of creating a personal relation with the Divine until achieving the final aim - deification or godlikeness.

Crucial for understanding the FCP method is to make a distinction between divine and human justice (Metropolitan Nahum of Strumica, 2015).

A criterion for man's guilt is the God-man Christ and divine justice, not man and human justice. What does this mean in practice? When man is hurt, in that moment he is not to think about whether he is justly or unjustly hurt, but his attention should be rather turned to whether his thoughts, words and deeds are in accordance with Christ's thoughts, words and deeds. Is the same happening in his mind and heart as is happening in Christ's mind and heart in a similar case? Does he act in the same manner as Christ did with those who hurt him? No, he is far away from Christ's reaction for sure. This is where his guilt lies, not from being justly or unjustly hurt; hence, the never-ending source of man's self-correction and spiritual progress (Митрополит Струмички Наум, 2018, p. 57).

It is important to emphasize that the use of the FCP method serves for a quick and unmistaken self-examination for the correctness of one's deeds. Namely, when facing a problem, stressful event or challenge, one examines himself according to the FCP method and immediately acts towards an implementation of the first point - acceptance, instead of nonacceptance - falling into a state of sorrow, suffering, depression and a process of long-lasting and exhausting grief. Briefly, they serve as reference points in respect to which one estimates his correct behavior, while the promptness of their use reflects the coefficient of one's spiritual intelligence (Митрополит Струмички Наум, 2015, pp. 59-67).

This is different from the phases described in contemporary psychology in dealing with loss, fatal disease or sorrow; most often the five described phases - denial, anger, bargaining, depression and acceptance (Kübler-Ross, 1969), which from the very beginning - denial of the current difficult situation, are followed by a long-lasting and painful process of grieving, pain and suffering, with an uncertain successful resolving. From experience, if this method that brings transformation is not used, then suppression is activated, which draws us into a new circulus vitiosus.

On the other hand, using the basic FCP method, in an act of his own free will, man voluntarily practices his personal ascesis.

The very first control point - acceptance, determines whether the primary or the secondary function of the mind is going to be activated. On one hand, the primary function of the mind is activated by acceptance and at this point, the process of transformation begins. On the other hand, non-acceptance activates the secondary function (the intellect), which is canalized through the ego apparatus, by mobilizing of the process of suppression through the defense mechanisms and developing a psychopathological condition - neurosis. 
Besides the above-mentioned, the practical use in managing of conditions with suicidal thoughts should be outlined, which makes the FCP method ultimately successful in their overcoming.

\section{Phases of Mental Disorders and Healing at the First Stage in Both Directions}

Contemporary psychopathology divides mental health deviations qualitatively into three nosological entities: neuroses, personality disorders and psychoses.

From the viewpoint of Christian psychotherapy, the above-mentioned clinical entities have a linear gradation and manifest themselves as three phases of mental disorders, which are outside the axis of spiritual development.

Neurosis is the first phase in the process of mental disorders. It is characterized by losing control over thoughts and feelings; the second phase is losing control over words; and the third phase - losing control over deeds.

In comparison to the above-mentioned, here follows a comparing parallel with the stages of spiritual growth, described as phases of healing.

First stage of spiritual growth - purification of the heart from the passions:

First phase: restraining from evil deeds.

Second phase: restraining from evil words.

Third phase: control over evil thoughts and feelings.

Neurosis ends with a personality disorder. The sufficient purification of the heart ends with illumination of the mind.

In both cases, all the phases are interconnected: the more one fails to control his thoughts and feelings, the more he is incapable of restraining from evil words, as well as from evil deeds. And vice versa: the more one manages to gain control over his thoughts and feelings, the more he is able to control his words and deeds.

The key point is in the control over the thoughts and feelings. This implies cognitive and emotional maturity. The control over thoughts and feelings depends on man's worldview or his beliefs.

The first and basic step is entering into obedience, that is, under the spiritual guidance of an experienced spiritual father psychotherapist, as a leader in the placing of one's mind into a process of healing, by which is realized the natural way of life as opposed to the counternatural.

The counternatural way of life is activated by the volitional and instinctive disinhibition of the id, which is the unconscious part of the human psyche where the primordial pulses lie - instincts, urges, desires, phantasies, whims, archaic contents - satisfying them according to the pleasure principle.

Furthermore, it is necessary to distinguish between the process of spiritual and mental disorders - a counternatural way of life, and the process of healing - a natural way of life; that is, between the three stages of personality development purification, illumination and deification, and the three stages of spiritual and mental disorders - neurosis, personality disorders and psychosis, in order to understand their mutual relatedness and to acquire knowledge of the harmony in spiritual life. The knowledge of both processes - at least theoretically - will be a great contribution to psychotherapy in general.

\section{The Healing Process - a Free and Perfectly Complete Person}

The perspective of Christian psychotherapy is a free and perfectly complete person. It is a person that - besides having a personal and socially useful role in family and society - has managed transpersonally to create new personal relations at the level of spiritual existence.

This process begins, above all, with obedience under the guidance of a spiritual father - psychotherapist and lasts until reaching the second stage of spiritual development, acquiring a new quality in one's personality; thus, man can independently ascend until the third stage, becoming a perfectly complete person. 
In psychological and spiritual sense, healing is a process that is interwoven with spiritual growth and development. It is a process of completing the imperfect being, which is re-created and transformed through metanoia; a process that takes place in five control points, in three development stages, by an aware differentiating between the two functions of the mind.

Only in this way can man accomplish his ultimate stage of spiritual development, becoming self-realized and self-actualized as a completion and wholeness according to the Image, in which he is created and for the purpose of which he is essentially determined.

\section{References}

[1] Bergson, H. (1911). Creative Evolution. New York, NY: Henry Holt and Company, p. 88.

[2] Frankl, V. E. (1992). Man's Search for Meaning. Boston, MA: Beacon Press, p. 10.

[3] Frankl, V. E. (1988). The Will to Meaning. New York, NY: Penguin Group, p. X.

[4] Freud, S. (1923). The Ego and the Id. In: Strachey J. et al. (Trans.), The Standard Edition of the Complete Psychological Works of Sigmund Freud, 19. London, England: Hogarth Press.

[5] Grinstead, D. (2015). The Psychology of Abraham Maslow. Atlantic University, p. 4. ResearchGate. doi: 10.13140/RG.2.1.4697.0407

[6] Hierotheos, Bishop of Nafpaktos (1994). Orthodox Psychotherapy. Levadia, Greece: Holy Monastery of Birth of Theotokos.

[7] Ilievski, N., Metropolitan of Strumica (2015). Basics of the Ascetical (Christian) Psychotherapy, Contributions. Sec. Med. Sci., 36(1), MASA, pp. 165-173.

[8] Ilievski, N., llievska, A. (2017, Sep.-Dec.). Sociological Dimensions of the FCP Method according to Christian Psychotherapy in Coping with Stress and Suffering, European Journal of Social Sciences, Education and Research, 11(1), pp. 93-98.

[9] llievski, N., llievska, A. (2018, Sep.-Dec.). Spiritual Development in Social Context: The Role of Christian Psychotherapy in the Formation of Identity, European Journal of Multidisciplinary Studies, 3(4), pp. 126-130.

[10] llievski, N., Jovkovska, A. (2018). The Orthodox Aspect of the Soul with Particular Focus on the Distinction between the Mind and the Intellect. The International Conference "On the Soul" - Book of papers, The Association of Comparative Literature of Macedonia ZKKM, The Association of Classical Philologists "Antika" and The Philosophical Society of Macedonia, June 1-3 2016, Skopje, Macedonia, pp. 189-200.

[11] James, M. (1981, Jaunary). TA in the 80's: The Inner Core and the Human Spirit. Transactional Analysis Journal, 11(1), pp. 54-65.

[12] James, W. (1917). The Varieties of Religious Experience. New York, NY: Longmans, Green, And Co, p. 515.

[13] Kübler-Ross, E. (1969). On Death and Dying [Kindle version]. Retrived from http://www.amazon.com

[14] Maslow, A. (1968). Toward a Psychology of Being. New York, NY: Van Nostrand Reinhold, p. 155.

[15] Migne, J.-P. (1994). Maximus Confessor, Ad Marinum Presbyterum. Patrologia Graeca, 91. Athens, Greece: Centre for Patristic Publications, 280a.

[16] Metropolitan Nahum of Strumica (2015). Only One Thing Is Needed [Kindle version]. Retrived from http://www.amazon.com

[17] Митрополит Струмички Наум (2015). Премин од душевност во духовност. Велјуса, Р. Македонија: Манастир Воведение на Пресвета Богородица Елеуса, pp. 59-67.

[18] Митрополит Струмички Наум (2016). Нови личносни односи. Велјуса, Р. Македонија: Манастир Воведение на Пресвета Богородица Елеуса, рp. 181-182. 
[19] Митрополит Струмички Наум (2018). Христијански идентитет. Велјуса, Р. Македонија: Манастир Воведение на Пресвета Богородица Елеуса, рp. 57; 173-174.

[20] Trautmann, R. L. (2003, January). Psychotherapy and Spirituality. Transactional Analysis Journal, 33(1), pp. 3236. 